\title{
Transdermal delivery of xenon from lipophilic solution and water
}

\author{
Alexander Yu. Verkhovskiy ${ }^{1 *}$, Dmitriy N. Atochin², Sergey N. Udintsev ${ }^{3}$, Sergey I. Tverdokhlebov ${ }^{4}$, Yana Anfinogenova ${ }^{5}$ and \\ Vladimir Yu. Serebrov ${ }^{6}$
}

*Correspondence: alverkhovniy@mail.ru

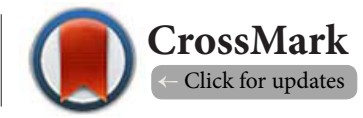

\begin{abstract}
${ }^{1}$ AleeXe Cosmetics Group Co., Limited, Hong Kong, Research Scientist, Laboratory of Technical Vision Systems, National Research Tomsk State University, 36 Lenina Ave, Tomsk, Russia.

${ }^{2}$ Assistant Professor of Medicine, Massachusetts General Hospital Cardiovascular Research Center, $14913^{\text {th }}$ Street, Charlestown, MA 02129, USA.

${ }^{3}$ Siberian State Medical University, 2 Moskovsky Trakt, 634050, Tomsk, Russia.

${ }^{4}$ Department of Theoretical and Experimental Physics, National Research Tomsk Polytechnic University, 30 Lenin Avenue, 634050, Tomsk, Russia.

${ }^{5}$ Research Scientist, Institute of Physics and Technology, National Research Polytechnic University, 30 Lenin Avenue, 634050, Tomsk, Russia; Federal State Budgetary Scientific Institution “Research Institute for Cardiology", 111a Kievskaya Street, 634012, Tomsk, Russia. ${ }^{6} \mathrm{Head}$ of Biochemistry Department, Siberian State Medical University, 2 Moskovsky Trakt, 634050, Tomsk, Russia.
\end{abstract}

\begin{abstract}
$\underline{\text { Aim: }}$ The purpose of the study was to characterize transdermal delivery of xenon through rat skin from a lipophilic solution and from water.

Methods: Sections of skin were obtained from adult rats $(\mathrm{n}=12)$ and were placed into static Franz diffusion cells for $24 \mathrm{~h}$. Xenon diffusion coefficients were determined for diffusion from a lipophilic solution $(\mathrm{n}=6)$ and from water $(\mathrm{n}=6)$ to phosphate buffered saline (PBS) through skin and for diffusion from a lipophilic solution to PBS through a phase boundary in the absence of skin $(n=6)$.

Results: Xenon flux $\left(\mathrm{J}_{\mathrm{xe}}\right)$ through skin from the lipophilic solution was $0.036 \mathrm{mg} / \mathrm{hour} \times \mathrm{cm}^{2}$ and permeability coefficient $\left(\mathrm{K}_{\mathrm{p}}\right)$ was $0.003 \mathrm{~cm} / \mathrm{h} ; \mathrm{J}_{\mathrm{Xe}}$ through skin from water was $0.029 \mathrm{mg} / \mathrm{h} \times \mathrm{cm}^{2}$ and the $\mathrm{K}_{\mathrm{p}}$ was $0.002 \mathrm{~cm} / \mathrm{h}$. Total time for xenon diffusion through skin from lipophilic solution and from water was $\sim 2 \mathrm{~h}$.
\end{abstract}

Conclusion: The study presents the first characterization of xenon diffusion through rat skin from multiphase solutions to PBS. These data may be useful for the development of xenon-rich pharmaceutical products for external use.

Keywords: Xenon, rat skin, transdermal delivery, franz diffusion cell

\section{Introduction}

Xenon has been considered an ideal anaesthetic agent due to rapid induction and emergence of anaesthesia, efficient analgesia, and low toxicity [1,2]. Moreover, xenon is known as a medication for treatment of pain, insomnia, depression, and drug addiction $[3,4]$. Also, scientific literature presents evidence of the neuroprotective effects of xenon [5] in treatment of traumatic [6] and ischemic [7] brain injury. Data suggest that blockade of NMDA receptors in the nervous system by xenon plays a key role in neuroprotective effects of this agent [5,8-10]. Recently, NMDA receptors have been found in the axons of human skin [15] and in the keratinocytes of the epidermis $[16,17]$. These receptors are involved in skin barrier function [18], calcium regulation [19], and dermatitis development [20]. We expect that xenon will exert similar blocking action when interacting with NMDA receptors in skin providing that this gas penetrates skin.

Earlier studies demonstrated xenon solubility in blood with solubility coefficients of 0.14 [11] and 0.115 [12]. These values are significantly higher than those for water: 0.085 [11] or 0.096 [12], but smaller than for oil: 1.7 [11]. Xenon is amphiphilic and able to dissolve in multiphase liquids, lipophilic, hydrophilic, 
Verkhovskiy et al. Dermatology Aspects 2015,

and emulsified solutions and so is promising for research, development, and implementation of intravenous and oral formulations delivering xenon to target receptors $[13,14]$.

The purpose of this work was to quantify xenon diffusion through rat skin from lipophilic solution and water.

\section{Materials and methods \\ Chemicals}

High purity xenon (>99.999\%, Tianjin Dongchuangrixing Technology Co. Ltd, CHINA) was used in the study. A universal cosmetic component, capryl/capric triglyceride (trade name: Tegosoft CT, Evonik Goldschmidt GmbH, Germany), was used as lipophilic solvent for xenon. Xenon was dissolved in capryl/capric triglyceride by using homogenizer (3000 rpm) with the airtight tank. Peristaltic pump was used to deliver exact amounts of xenon. Detailed protocol for the process of dissolving xenon in liquids is described in the patent [21]. Phosphate buffered saline (PBS, $\mathrm{pH}=7.4$ ) was prepared by using high purity chemical reagents (Seebio Biotech, Inc., China). Urethane (Shanhai Jinsul Bio-Technology Co., Ltd, China) was used for anaesthesia.

\section{Skin preparation}

Full-thickness skin preparations (epidermis and derma) were obtained from 3-month-old male Wistar rats (220 to $290 \mathrm{~g}$ ). All operations with laboratory animals were performed according to international standards (Ethics Committee of Siberian State Medical University, Resolution \# 3886). Animal skin samples were obtained under general anaesthesia induced by infusion of $20 \%$ urethane solution ( $1 \mathrm{~mL} / 100 \mathrm{~g}$ of body weight). When rats were under anaesthesia, abdominal skin surface was depilated with scissors and electric shaver avoiding skin damage. Dissected patch of skin was rinsed with $0.9 \%-\mathrm{NaCl}$ saline solution and carefully cleaned of residual connective and adipose tissue so that only derma remained. Round preparations with diameter of 3.2 to $3.4 \mathrm{~cm}$ were dissected from the skin patch. Prepared skin samples were immediately mounted in the diffusion cells between the receptor and donor chambers. The receptor chamber was filled with PBS solution $(8 \mathrm{~mL})$; air bubbles were extracted from the solution;then the PBS solution was stabilized at the receptor chamber temperature of $37^{\circ} \mathrm{C}$ for $1 \mathrm{~h}$. This methodology assured that the skin surface facing the donor chamber was maintained at $32^{\circ} \pm 0.1^{\circ} \mathrm{C}$ during the entire experiment.

\section{In vitro permeation study}

All experiments were divided into three groups. In Group 1, we quantified xenon diffusion from lipophilic capryl/capric triglyceride to PBS solution. Group 1 results are essential to assess skin barrier function in xenon diffusion. In Group 2, we used lipophilic capryl/capric triglyceride to create a high xenon concentration in contact with the skin. Capryl/capric triglyceride and the stratum corneum of the skin are both lipophilic. It is good for xenon mass transport. In Group 3, we eliminated the close contact between lipophilic capryl/ capric triglyceride and the surface of the skin by adding a layer of water between the skin and the triglyceride.The results of this group show the diffusion of xenon through the skin from the water.

All experiments were performed in static Franz diffusion cells (PermeGear Inc., USA); a standard for studying dermal permeability in vitro $[\mathbf{2 2}, \mathbf{2 3}]$. Sets of three Franz diffusion cells were used in all experiments. The orifice area between the donor and receptor chambers was $1 \mathrm{~cm}^{2}$, the donor chamber volume was $2 \mathrm{~mL}$ and the receptor chamber volume was 8 $\mathrm{mL}$. Receptor chamber content was continuously mixed with a magnetic stirrer (600 rpm). Receptor chamber temperature was maintained at $37^{\circ} \mathrm{C}$ by using an ultra-thermostat SC-15 (NingBo Scientz Biotechnology Co., Ltd, China,).

Control parameters of xenon diffusion were obtained without skin when xenon diffused directly through the interphase boundary from capryl/capric triglyceride to PBS solution (control group, Group 1).

Receptor chambers were filled with $8 \mathrm{~mL}$ of PBS and allowed to come to the equilibrium temperature, $37^{\circ} \mathrm{C}$, for 1 hour. Donor chambers were then top-filled with $1 \mathrm{~mL}$ of capryl/capric triglyceride saturated with xenon and sealed. An interphase boundary between capryl/capric triglyceride and PBS demarcated the boundary between donor and receptor chambers so that the diffusion system was formed as follows: xenon-rich capryl/capric triglyceride-PBS (Figure 1, Group 1).

In Group 2, $1 \mathrm{~mL}$ of xenon-rich capryl/capric triglyceride solution (Figure 1, Group 2) was applied to the skin, mounted between the donor and receptor chambers, to study xenon

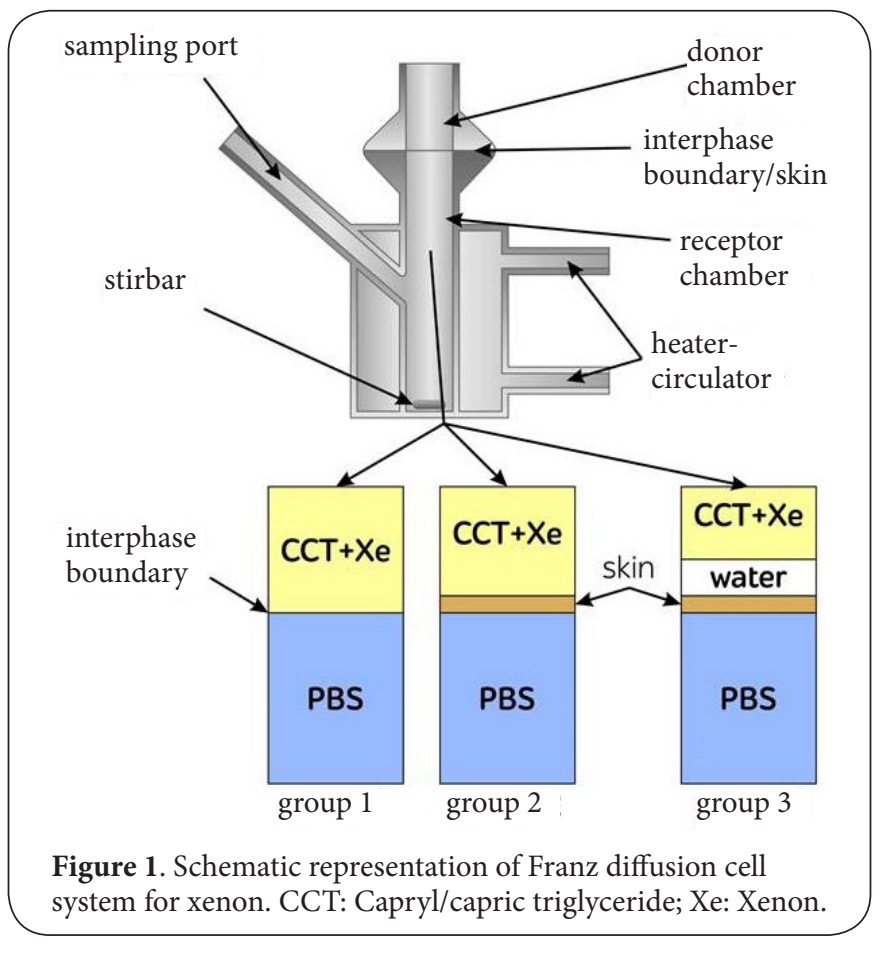


Verkhovskiy et al. Dermatology Aspects 2015,

diffusion through skin from a lipophilic media. This diffusion system configuration is: xenon-rich capryl/capric triglycerideskin-PBS.

In Group 3, $0.5 \mathrm{~mL}$ of water was first applied to the skin surface. Then, $1 \mathrm{~mL}$ of xenon-rich capryl/capric triglyceride solution was carefully applied over the water layer (Figure 1, Group 3). Contact of capryl/capric triglyceride with skin was thus avoided. In this setup, the xenon-rich capryl/capric triglyceride solution was a source of xenon for the water layer that was adjacent to skin surface. This approach enabled us to achieve high xenon content in the water layer to establish the diffusion system of xenon-rich water-skin-PBS. In preliminary experiments, we tested xenon diffusion from capryl/ capric triglyceride solution into water through the interphase boundary similarly to control Group 1. After maintaining the system for 2 hours, xenon content in water in the receptor chamber was $1.453 \pm 0.043 \mathrm{mg}(\mathrm{n}=3)$.

After addition of $1 \mathrm{~mL}$ of xenon-rich capryl/capric triglyceride, the donor chambers were sealed. Samples $(1 \mathrm{~mL})$ were taken from the receptor chambers every 2 hours for 24 hours for xenon analysis. Precautions were taken to prevent the entry of air into the system. After each sampling event, $1 \mathrm{~mL}$ of PBS was immediately added back into the receptor chamber to maintain constant volume. The extracted samples were immediately placed into the custom $20-\mathrm{mL}$ glass containers and sealed. Xenon content in the samples was determined by gas chromatography.

\section{Tests}

Xenon content in the samples was determined by using a gas chromatograph Agilent 7697A, 7890A (Agilent Technologies, USA). Headspace analysis in the presence of thermodynamic equilibrium was used to measure xenon content in the liquids. Calibration was carried out at $20^{\circ} \mathrm{C}$ by injecting pure xenon in $0.1 \mathrm{~mL}(0.549 \mathrm{mg})$ increments up to $2.5 \mathrm{~mL}(13.725 \mathrm{mg})$ into the $20-\mathrm{mL}$ airtight containers that were empty or had $1 \mathrm{~mL}$ of the test liquid with and without xenon. Sample volume was $1 \mathrm{~mL}$ and the container volume was $20 \mathrm{~mL}$. Conditions of xenon content measurements were as follows: temperature of $250^{\circ} \mathrm{C}$, pressure of $5.9204 \mathrm{psi}$, and purge flow rate of $2 \mathrm{~mL} /$ min. Helium was used as carrier gas. Steady-state flow rate in chromatographic column (length of $30 \mathrm{~m}$; inner diameter of $0.53 \mathrm{~mm}$ ) was $4 \mathrm{~mL} / \mathrm{min}$ at initial temperatures of $50^{\circ} \mathrm{C}$ to $120^{\circ} \mathrm{C}$. Temperature of termodesorber's detector was $300^{\circ} \mathrm{C}$, flow rate was $10 \mathrm{~mL} / \mathrm{min}$ and the signal was $5 \mathrm{HZ} / 0.04 \mathrm{~min}$. Sample testing lasted for 0.5 min at gas chromatography cycle of $15 \mathrm{~min}$.

\section{Data analysis}

Xenon diffusion was studied for 24 consecutive hours; xenon content in the samples was determinedevery two hours. Based on the xenon concentration in $1 \mathrm{~mL}$ of PBS, we calculated total amount of xenon $(\mathrm{Q})$ in the receptor chamber as a function of time. The flux (J) was calculated as amount of xenon (mg) crossing $1 \mathrm{~cm}^{2}$ of interphase boundary per $1 \mathrm{~h}$. Under steady-state conditions with constant xenon flow rate, the permeability coefficient $\left(\mathrm{K}_{\mathrm{p}}\right)$ was calculated by formula: $\mathrm{K}_{\mathrm{p}}=\mathrm{J} / \mathrm{C}_{\mathrm{d}}$

where $C_{d}$ is xenon concentration in capryl/capric triglyceride in the donor chamber [24].

Each series consisted of six experiments. Data are presented as the mean $\pm S D$ calculated in Microsoft Excel. For comparison of Group 2 and Group 3, values were considered statistically significant when $\mathrm{P}$ was $<0.05$ (Student's t-test).

\section{Results}

Initial concentration of xenon in capryl/capric triglyceride solution was $12.225 \pm 0.074 \mathrm{mg} / \mathrm{mL}(\mathrm{n}=18)$. Figure 2 shows total amount of xenon $(\mathrm{mg})$ in $8 \mathrm{~mL}$ and is the amount of xenon that has diffused through the interphase boundary (Group 1), through the skin from lipophilic media (Group 2) and through the lipophilic-hydrophilic media (Group 3, respectively). Figure 3 shows increasing xenon concentrations at different time points for the systems of diffusion through skin from the lipophilic (Group 2: solid line) and hydrophilic media (Group 3: dashed line). The figure shows that the difference between xenon diffusion in Group 2 and Group 3 occurs after hour 10. Therefore, the nature of the solvent does not significantly affect the diffusion during the first eight hours.

Table 1 presents calculated xenon flux $(J)$ and permeability coefficient $\left(\mathrm{K}_{\mathrm{p}}\right)$.

Transdermal xenon transport obeys Fick's first law of diffusion where in the diffusive flux $J$ and is characterized by the amount of matter transferred through a unit of skin surface area per a unit of time. $\mathrm{K}_{\mathrm{p}}$ can be calculated from the relationship $\left.K_{p}=Q /\left[A_{d}-C_{r}\right)\right]$ where $Q$ is the total amount of xenon travers-

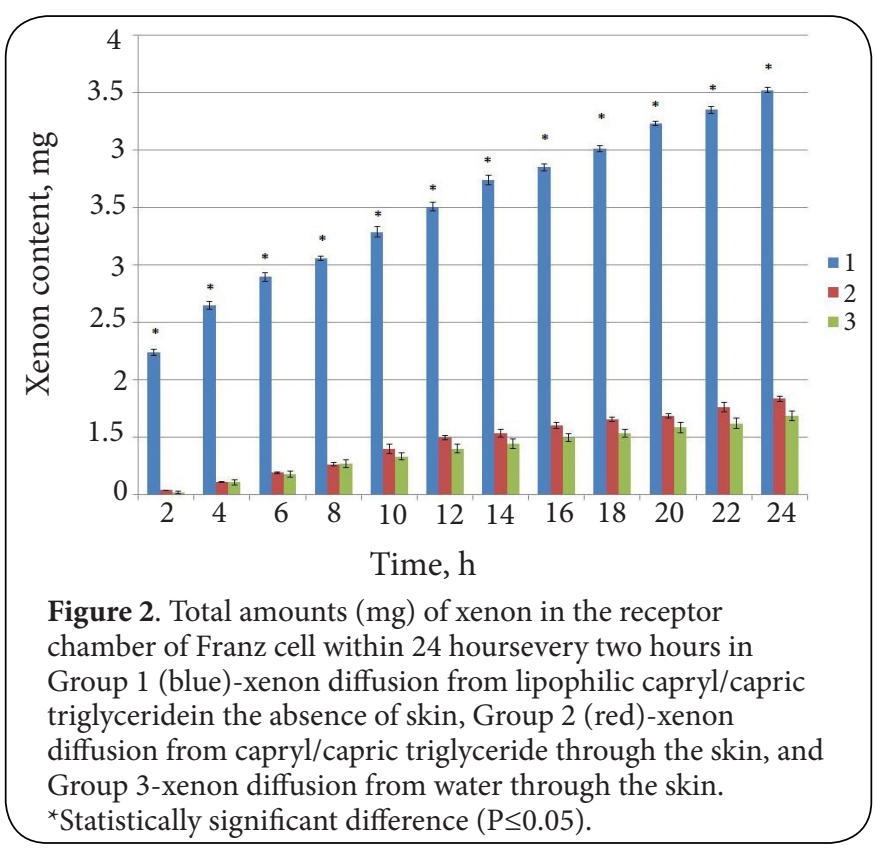




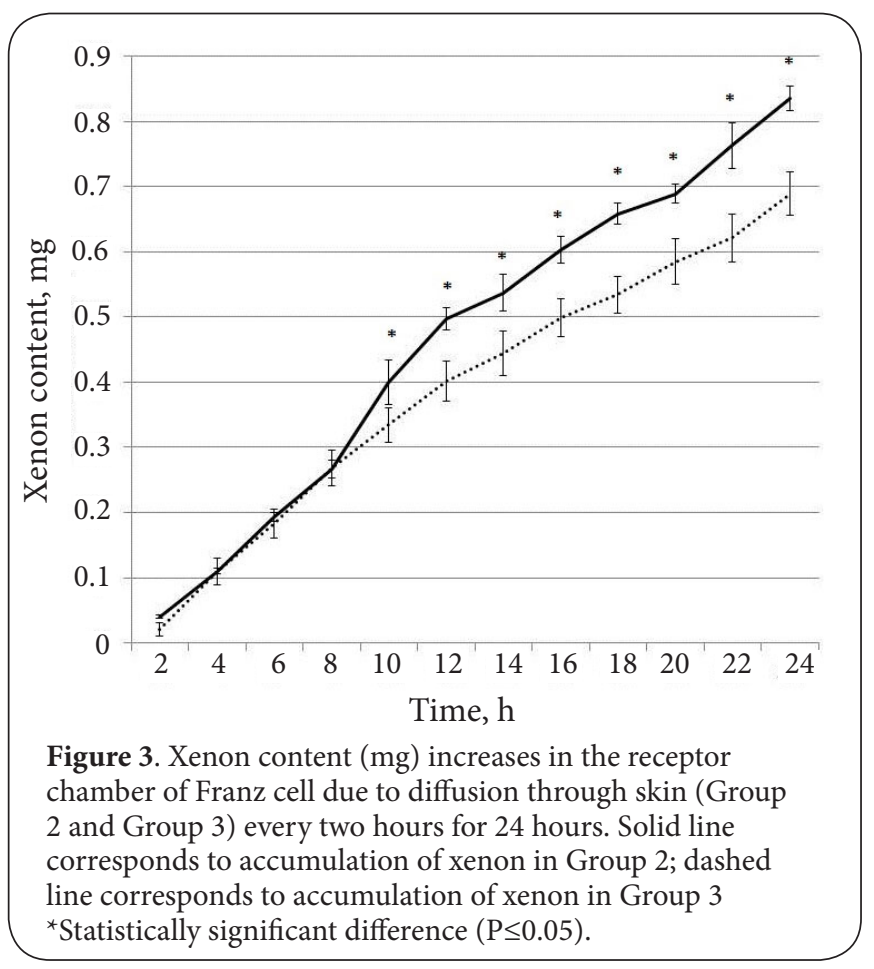

Table 1. Mean values of flow $(J)$ and permeability coefficient $\left(K_{p}\right)$ for xenon for all experimental Groups.

\begin{tabular}{lll}
\hline & $\mathbf{J}, \mathbf{~ m g} / \mathbf{h} \times \mathbf{c m}^{2}$ & $\mathbf{K}_{\mathbf{p}}, \mathbf{c m} / \mathbf{h}$ \\
\hline Group 1 & 0.099 & 0.008 \\
Group 2 & 0.036 & 0.003 \\
Group 3 & 0.029 & 0.002 \\
\hline
\end{tabular}

ing the membrane in time $t$, and $A$ is the area of exposed membrane in $\mathrm{cm}^{2}, C_{d}$ is the concentration of the xenon on the donor chamber and $\mathrm{C}_{r}$ is the concentrations of the xenon on the receptor chamber. Usually $C_{d}$ can be simplified as the donor concentration and $C_{r}$ as 0 . The units of $K_{p}$ are $\mathrm{cm} / \mathrm{h}$. The permeability coefficient $K_{p}$ describes the rate of penetration.

\section{Discussion}

We present results on transdermal delivery of xenon. Transdermal delivery is typically studied by using skin preparations from humans, pigs, and other laboratory animals including rodents $[25,26]$. It is important to note that comparative results for penetration of different compounds through the skin of different species, including hairless mice and humans, depend on the physical-chemical properties of the substances [27]. A lot of work has been done on rat skin and and rat skin is a relevant model $[\mathbf{2 8 , 2 9 ]}$. In this study we present data on transdermal delivery for xenon for the first time. In Group 2 and Group 3, we detected xenon in the receptor chamber after 2 hours which represents the time for diffusion through skin. In Group 3, we identified xenon in only 3 out of 6 cases.
Water is an additional pathway for diffusion. During the period from 4 to 8 hours, xenon diffusion rates did not differ between Group 2 and Group 3. Data on xenon diffusion through skin from $10 \mathrm{~h}$ to $24 \mathrm{~h}$ in Group 3 can be explained by the fact that the presence of water adjacent to the skin surface increased time of xenon diffusion as the mean xenon diffusion rate decreased (by 17.5\%). During this period, the decrease in diffusion could be caused by hydration of the epidermis. Hydration can induced skin swelling, thickening, and alteration of horny layer architectonics [30-33]. When the distance of xenon diffusion through the skin increases, diffusion rate decreases.

Comparison of diffusion rates for xenon diffusion from capryl/capric triglyceride to receptor chamber through the interphase boundary with no skin (Group 1) and through the skin (Group 2) demonstrated that the presence of skin slows down diffusion by $\sim 31$ times compared to the $2 \mathrm{~h}$ time point. Complete penetration of xenon through skin, as evidenced by detection of this gas in the receptor chamber, took $\sim 2 \mathrm{~h}$. After $2 \mathrm{~h}$, the difference in diffusion rates gradually decreased 15 fold at 4 hand 7.7 fold at $8 \mathrm{~h}$. Starting from 10 $\mathrm{h}$ and throughout the rest of the experiment, this difference continued to decrease from 5.7 to 4.2 times. These data are important because they demonstrate the time of saturation of the skin with xenon. High xenon solubility in lipophilic liquids enabled us to achieve high topical xenon concentration on the skin surface ensuring the possibility of transdermal diffusion through all skin layers and water layer. In our study, xenon concentration in capryl/caprictriglyceride corresponded to its solubility coefficient of 1.2-1.3. At such concentrations, xenon-rich lipophilic solution remains stable and can be used for several months if stored in an airtight container.

Our data on transdermal diffusion of xenon through skin from multiphase solutions offer exciting possibilities for the development of xenon-rich medications designed for external use. The proposed mechanism of action of these medications is blockade of NMDA receptors by xenon. There is evidence that efficacy of many agents designed for treatment of dermal diseases associated with pain syndromes depends on their ability to suppress the activity of NMDA receptors (NMDA receptors antagonists) [34]. Continuing research and development of xenon-rich compounds for medicinal use requires further experiments done on different skin types including human preparations. Next steps will involve studying the effects of xenon on the activity of NMDA receptors in the skin and comparing with other known antagonists of NMDA receptors. In summary: xenon is a promising agent for anesthesia and therapy. It could be used separately or in a combination with other biologically active substances or enhancers. Mechanisms of xenon effects on skin and modalities of delivery require further studies.

\section{Conclusions}

1. In vitro transdermal diffusion of xenon from lipophilic 
Verkhovskiy et al. Dermatology Aspects 2015,

solution of capryl/capric triglyceride and from water was characterized. Diffusion parameters flow $(J)$ and permeability coefficient $\left(\mathrm{K}_{\mathrm{p}}\right)$ were identified.

2. Diffusion rate for xenon diffusion through skin from water was significantly lower (17.5\%) than t diffusion from capryl/ capric triglyceride solution for the time points from $10 \mathrm{~h}$ to $24 \mathrm{~h}$. 3. Time for xenon penetration from capryl/capric triglyceride solution and from water through rat skin was $2 \mathrm{~h}$.

\section{Competing interests}

The authors declare that they have no competing interests.

\section{Authors' contributions}

\begin{tabular}{|l|c|c|c|c|c|c|}
\hline Authors' contributions & AYV & DNA & SNU & SIT & YJA & VYS \\
\hline Research concept and design & $\checkmark$ & -- & -- & -- & -- & -- \\
\hline Collection and/or assembly of data & $\checkmark$ & -- & -- & -- & -- & -- \\
\hline Data analysis and interpretation & $\checkmark$ & -- & -- & $\checkmark$ & -- & -- \\
\hline Writing the article & $\checkmark$ & -- & $\checkmark$ & -- & $\checkmark$ & -- \\
\hline Critical revision of the article & $\checkmark$ & $\checkmark$ & -- & -- & $\checkmark$ & $\checkmark$ \\
\hline Final approval of article & $\checkmark$ & $\checkmark$ & $\checkmark$ & -- & -- & -- \\
\hline Statistical analysis & $\checkmark$ & -- & -- & $\checkmark$ & -- & -- \\
\hline
\end{tabular}

\section{Acknowledgements}

The work was done in a framework of the programme for development of competitiveness of the National Research Tomsk State University. The authors are very thankful to administration of Xiaoyu, Ltd (Yingkou, China) Cui Jun Feng and Qin Bang Guo for financial support. However, the financial support provided was not rekated to research done, it covered household expenses only. and also to Professor Yuri Anissimov (Griffith University, Australia) for help with data processing.

Publication history

Editors: Howard Ira Maibach, University of California, USA.

Marna Elise Ericson, University of Minnesota, USA.

Received: 26-Feb-2015 Final Revised: 10-Jul-2015

Accepted: 14-Jul-2015 Published: 27-Jul-2015

\section{References}

1. Joyce JA. Xenon: anesthesia for the 21st century. AANA J. 2000; 68:25964. I PubMed

2. Jordan $\mathrm{BD}$ and Wright EL. Xenon as an anesthetic agent. AANA J. 2010; 78:387-92. | Pdf | PubMed

3. Sanders RD, Franks NP and Maze M. Xenon: no stranger to anaesthesia. BrJ Anaesth. 2003; 91:709-17. | Article | PubMed

4. Abraini JH, David $\mathrm{HN}$ and Lemaire M. Potentially neuroprotective and therapeutic properties of nitrous oxide and xenon. Ann N Y Acad Sci. 2005; 1053:289-300. | Article | PubMed

5. Esencan E, Yuksel S, Tosun YB, Robinot A, Solaroglu I and Zhang JH. XENON in medical area: emphasis on neuroprotection in hypoxia and anesthesia. Med Gas Res. 2013; 3:4. | Article | PubMed Abstract | PubMed Full Text

6. Campos-Pires R, Armstrong SP, Sebastiani A, Luh C, Gruss M, Radyushkin K, Hirnet T, Werner C, Engelhard K, Franks NP, Thal SC and Dickinson R. Xenon improves neurologic outcome and reduces secondary injury following trauma in an in vivo model of traumatic brain injury. Crit Care Med. 2015; 43:149-58. | Article | PubMed

7. Muller AJ and Marks JD. Hypoxic ischemic brain injury: Potential therapeutic interventions for the future. Neoreviews. 2014; 15:e177-e186. | Article | PubMed Abstract | PubMed Full Text
8. Ma D, Wilhelm S, Maze M and Franks NP. Neuroprotective and neurotoxic properties of the 'inert' gas, xenon. Br J Anaesth. 2002; 89:739-46. | Article | PubMed

9. Petzelt C, Blom P, Schmehl W, Muller J and Kox WJ. Xenon prevents cellular damage in differentiated PC-12 cells exposed to hypoxia. $B M C$ Neurosci. 2004; 5:55. | Article | PubMed Abstract | PubMed Full Text

10. Dingley J, Tooley J, Porter H and Thoresen M. Xenon provides short-term neuroprotection in neonatal rats when administered after hypoxiaischemia. Stroke. 2006; 37:501-6. | Article | PubMed

11. Steward A, Allott PR, Cowles AL and Mapleson WW. Solubility coefficients for inhaled anaesthetics for water, oil and biological media. Br J Anaesth. 1973; 45:282-93. | Article | PubMed

12. Goto T, Suwa K, Uezono S, Ichinose F, Uchiyama M and Morita S. The blood-gas partition coefficient of xenon may be lower than generally accepted. Br J Anaesth. 1998; 80:255-6. | Article | PubMed

13. Benrath J, Kempf C, Georgieff M and Sandkuhler J. Xenon blocks the induction of synaptic long-term potentiation in pain pathways in the rat spinal cord in vivo. Anesth Analg. 2007; 104:106-11. | Article | PubMed

14. Weigt $\mathrm{HU}$, Georgieff M, Fohr KJ and Adolph O. In vitro-evaluation of lipid emulsions as vehicles for the administration of xenon: interaction with NMDA receptors. Acta Neurobiol Exp (Wars). 2009; 69:207-16. | PubMed

15. Kinkelin I, Brocker EB, Koltzenburg M and Carlton SM. Localization of ionotropic glutamate receptors in peripheral axons of human skin. Neurosci Lett. 2000; 283:149-52. | Article | PubMed

16. Fuziwara $S$, Inoue $K$ and Denda M. NMDA-type glutamate receptor is associated with cutaneous barrier homeostasis. J Invest Dermatol. 2003; 120:1023-9. | Article | PubMed

17. Fischer M, Glanz D, William T, Klapperstuck T, Wohlrab J and Marsch W. $\mathrm{N}$-methyl-D-aspartate receptors influence the intracellular calcium concentration of keratinocytes. Exp Dermatol. 2004; 13:512-9. | Article I PubMed

18. Morhenn VB, Murakami M, O'Grady T, Nordberg J and Gallo RL. Characterization of the expression and function of $\mathrm{N}$-methyl-Daspartate receptor in keratinocytes. Exp Dermatol. 2004; 13:505-11. | Article I PubMed

19. Nahm WK, Philpot BD, Adams MM, Badiavas EV, Zhou LH, Butmarc J, Bear MF and Falanga V. Significance of N-methyl-D-aspartate (NMDA) receptor-mediated signaling in human keratinocytes. J Cell Physiol. 2004; 200:309-17. | Article | PubMed

20. Tan PH, Yang LC, Chiang PT, Jang JS, Chung HC and Kuo CH. Inflammationinduced up-regulation of ionotropic glutamate receptor expression in human skin. Br J Anaesth. 2008; 100:380-4. | Article | PubMed

21. VerkhovskiyAYu, Udintsev SN. Installation for injection of xenon gas into liquid media. Patent of RF RU 123685.

22. Friend DR. In vitro skin permeation techniques. J Control Release. 1992; 18:235-248. | Article

23. Bartosova $L$ and Bajgar J. Transdermal drug delivery in vitro using diffusion cells. Curr Med Chem. 2012; 19:4671-7. | Article | PubMed

24. Geethu VS, Manikandan P, Nethaji R, Surenderan NS and Babu G. A review on: transdermal drug delivery systems. IAJPR. 2014; 4:18091824.

25. Zadeh BSM and Hasani MH. The effect of chemical and physical enhancers on trolamine salicylate permeation through rat skin. TJPR. 2010; 9:541-548. I Pdf

26. Bektas A, Cevher E, Gungor S and Ozsoy Y. Design and evaluation of polysaccharide-based transdermal films for the controlled delivery of nifedipine. Chem Pharm Bull (Tokyo). 2014; 62:144-52. | Article | PubMed

27. Simon GA and Maibach HI. Relevance of hairless mouse as an experimental model of percutaneous penetration in man. Skin Pharmacol Appl Skin Physiol. 1998; 11:80-6. | Article | PubMed

28. Scott RC, Dugard PH, Ramsey JD and Rhodes C. In vitro absorption of some o-phthalate diesters through human and rat skin. Environ Health Perspect. 1987; 74:223-7. | PubMed Abstract | PubMed Full Text

29. Barber ED, Teetsel NM, Kolberg KF and Guest D. A comparative study of 
Verkhovskiy et al. Dermatology Aspects 2015,

http://www.hoajonline.com/journals/pdf/2053-5309-3-2.pdf

the rates of in vitro percutaneous absorption of eight chemicals using rat and human skin. Fundam Appl Toxicol. 1992; 19:493-7. | Article | PubMed

30. Potts RO, Golden GM, Francoeur ML, Mak VHW and Guy RH. Mechanism and enhancement of solute transport across the stratum corneum. $J$ Control Release. 1991; 15:249-260. | Article

31. Liron Z, Wright RL and McDougal JN. Water diffusivity in porcine stratum corneum measured by a thermal gravimetric analysis technique. $J$ Pharm Sci. 1994; 83:457-62. | Article | PubMed

32. Bouwstra JA, de Graaff A, Gooris GS, Nijsse J, Wiechers JW and van Aelst AC. Water distribution and related morphology in human stratum corneum at different hydration levels. J Invest Dermatol. 2003; 120:7508. | Article | PubMed

33. Warner RR, Stone KJ and Boissy YL. Hydration disrupts human stratum corneum ultrastructure. J Invest Dermatol. 2003; 120:275-84. | Article | PubMed

34. Scheinfeld N. Topical treatments of skin pain: a general review with a focus on hidradenitis suppurativa with topical agents. Dermatol Online J. 2014; 20. | Article | PubMed

\section{Citation:}

Verkhovskiy AY, Atochin DN, Udintsev SN, Tverdokhlebov SI, Anfinogenova Y and Serebrov VY. Transdermal delivery of xenon from lipophilic solution and water.

Dermatol Aspects. 2015; 3:2.

http://dx.doi.org/10.7243/2053-5309-3-2 